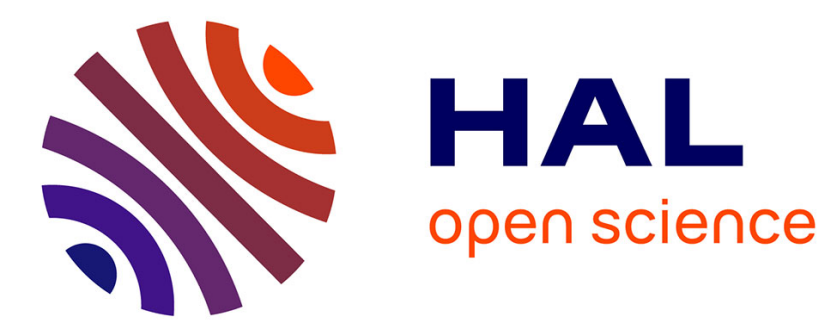

\title{
Corporate Responsibility in the Environmental Protection as an Element of Public-Private Partnership in Ukraine
}

\author{
Anatoliy V Kostruba
}

\section{- To cite this version:}

Anatoliy V Kostruba. Corporate Responsibility in the Environmental Protection as an Element of Public-Private Partnership in Ukraine. Public Policy and Administration, 2021, 20 (1), pp.118-126. 10.5755/j01.ppaa.20.1.28344 . hal-03214257

\section{HAL Id: hal-03214257 \\ https://hal.science/hal-03214257}

Submitted on 1 May 2021

HAL is a multi-disciplinary open access archive for the deposit and dissemination of scientific research documents, whether they are published or not. The documents may come from teaching and research institutions in France or abroad, or from public or private research centers.
L'archive ouverte pluridisciplinaire HAL, est destinée au dépôt et à la diffusion de documents scientifiques de niveau recherche, publiés ou non, émanant des établissements d'enseignement et de recherche français ou étrangers, des laboratoires publics ou privés. 


\title{
Corporate Responsibility in the Environmental Protection as an Element of Public-Private Partnership in Ukraine
}

\author{
Anatoliy V. Kostruba \\ Vasyl Stefanyk Precarpathian National University \\ 676000, 57 Shevchenko Str., Ivano-Frankivsk, Ukraine \\ cross' $^{\text {ref }}$ http://dx.doi.org/10.5755/j01.ppaa.20.1.28344
}

\begin{abstract}
Individual and corporate responsibility is the basis for sustainable development of society and the world. Environmental responsibility of business entities is a prerequisite for the survival of people, which is why it is an important aspect of corporate responsibility. The purpose of the paper is to determine the content of corporate and social responsibility of business entities in the field of environmental protection in terms of its interaction with the state on the basis of publicprivate partnership. The general scientific method of comparison made it possible to compare the Ukrainian legislative base on environmental protection with the legal framework of regulation and practice in foreign countries. Through the structural and functional analysis, it was possible to consider the features of the interaction between the state and business structures and between other institutions the activities of which are related to environmental protection. The analysis revealed the necessity to consider and include elements of environmental and social responsibility of business in the mechanisms of public-private partnership. The study shows that public-private partnership is an imperative element in the composition of social responsibility. The author proposes a definition of environmental responsibility that encompasses three factors: legal, economic and social. In the future, this research area will be of interest as a comparison of the legislative support of the types of responsibility for foreign and international standards in the context of implementing the relevant standards in the Ukrainian legislative framework and their implementation on practice.
\end{abstract}

Keywords: social responsibility, environmental legislation, public-private partnership

Raktažodžiai: socialinè atsakomybé, aplinkosaugos istatymai, viešojo ir privataus sektoriaus partneryste

\section{Introduction}

Today, the state of the environment cannot be called ideal: the world's population is faced with various types of environmental problems. Often, however, global environmental issues fade into the background as a result of the constant pursuit of profit. Human activities such as deforestation for agricultural and commercial purposes, burning of fossil fuel and changes in the use of land due to the population growth are contributing significantly to a surge in greenhouse gas emissions. Many countries are facing high levels of carbon dioxide in the environment due to energy consumption and economic growth (Zhupysheva et al., 2019). Energy consumption and economic growth are the two most common drivers of $\mathrm{CO} 2$ emissions. Efforts are being made at the global scene to further prevent the effects of $\mathrm{CO} 2$ emissions by fostering a low-carbon economy. According scientists, it is necessary that emission standards should be set for industries and emission monitoring strategies should be put in place (Getman, 2020; Osobajo, et al., 2020). In addition, measures to curb deforestation should be strengthened, since these activities release $\mathrm{CO} 2$ emissions into the atmosphere.

Every company that strives for success and wants to achieve considerable results should adhere to environmental legislation, as well as take an active socially responsible position and try to contribute to the health of the planet with the help of various environmental projects (Lutkovska, 2020a). Environmental responsibility should play one of the key roles in every company, regardless 
of its sphere of activity, as environmental responsibility of business entities is a prerequisite for the survival of people. Therefore, individual and corporate responsibility is the basis for sustainable development of society and the world. Socially responsible businesses recognise the equality of socioenvironmental and financial-economic interests and values: they pay attention to the development of non-financial factors (quality personnel policy, environmental management, reputation, image, etc.). A responsible attitude to environmental protection is an essential component of corporate social responsibility (Zhigir, 2020). Socially responsible business entities strictly follow the principle of compliance with applicable environmental laws and take into account environmental risks in their activities. Searching for tools and mechanisms to achieve agreement and establishing interaction between interested parties, i.e., business, the state represented by government and society, is therefore an important task for those who are active in the field of environmental management and environmental protection. These aspects indicate the relevance of this research and determined the subject of the paper.

The beginning of an active public discussion about environmental issues dates back to the 1970s, when the group of Meadows (1972), using mathematical modeling methods, prepared a report on the forecasts of changes in the environment and the future of human civilisation and presented it to the Club of Rome. According to the apocalyptic results of research, humanity would only live a full life for a few decades, and then a collapse would occur : the depletion of soil resources will lead to the inability to provide the planet's population with enough food, environmental pollution will lead to irreversible consequences for human health, etc. (Meadows et al., 1972). The report caused a wave of heated discussions at various levels. It became obvious that without the introduction of a concept of environmental responsibility in all spheres of society, an environmental catastrophe was imminent.

Since then, research in this direction has intensified. Issues of introduction and implementation in the business environment of the principles of social responsibility of business entities have been investigated by a number of Ukrainian researchers, e.g., Alekseeva (2008), Vorobey (2005), Ladunka and Simonenko (2017), Malinovska (2008), Saprykina (2008), Chernykh (2009), Yarova (2013) and others. Among scientists from the countries of the post-Soviet space who study the issues of social responsibility of business entities and the environmental problem as its component, the following authors should be mentioned: Aleksandrova (2019), Kopytova (2017), Postal and Komelkova (2017), Shevchenko (2015), Uskova and Kopytova (2016) and others. However, issues related to the formation of a model for introducing social responsibility of business entities within the environmental component remain controversial and open, both in Ukrainian practice and international level. The purpose of the paper is to determine the content of corporate and social responsibility of the business entities in the field of environmental protection in the context of its interaction with the state on the terms of public-private partnership.

\section{Methodology}

To achieve the objective of the study, a system of cognition methods for social and legal phenomena was applied. The general scientific method of comparison made it possible to compare the Ukrainian legislative base on environmental protection with the legal framework of regulation and practice in foreign countries. The historical method was used to determine the chronological transformations of Ukrainian and international environmental laws regarding the practice and development of corporate responsibility in this area. The analytical method facilitated the assessment of the level of compliance by Ukrainian's companies with environmental standards and the implementation of public-private partnerships in this field. One of the instruments was the typological method, which made it possible to classify possible types of public-private partnerships in the field of environmental protection. The genetic method made it possible to identify the stages in the development of public-private partnerships in the field of environmental protection and under the influence of what factors its norms have changed. Through the structural and functional analysis, it was possible to consider the features of the interaction between the state and business structures and 
between other institutions the activities of which are somehow related to environmental protection, as well as systematise information about its effectiveness both in Ukraine and abroad.

The theoretical basis of the study consisted of the following Laws of Ukraine: "On Basic Principles (Strategy) of the State Environmental Policy of Ukraine for the Period to 2030" (2019), "On Environmental Protection" (1991), "On Protection of Atmospheric Air" (1992), "On Natural Reserve Fund of Ukraine" (1992). The analysis of the scientific literature on the subject matter with the use of these methods was conducted in order to give an exhaustive description of the system of corporate and social responsibility of business entities in the environmental protection field on the basis of public-private partnership in Ukraine. The methods used made it possible to obtain reliable and reasonable conclusions and results, which, using the descriptive method, are presented in a logical and chronological sequence.

\section{Results and Discussion}

Social responsibility of business entities is not a new phenomenon. The basic tenets of the concept of social responsibility of business entities were provided in detail back in the 1950s. Social responsibility is seen as the duty of a business to pursue that policy, take management decisions and follow those areas of activity that are desirable from the point of view of the goals and values of society. These actions include employment; respect for human rights and the elimination of discrimination; creation of decent living conditions and wages for employees; occupational safety and health; staff training and education; customer support; compliance with all legal and ethical business standards; participation in the development of the local community; charity; setting higher standards of performance; environmental protection, etc. (Bowen, 1953).

The concept of social responsibility already implies a wide range of issues of interaction between owners, colleagues, business partners, government agencies, public organisations and members of society. Some authors note it as an interaction of "business and government" or "business, state and society" (Krupina, 2006; Zhornokui and Slipchenko, 2020). That is, it is possible to say that public-private partnerships are an imperative element in the composition of social responsibility. Social responsibility comes in various forms and is implemented through various measures, acting as a consensual toolkit between the interests and activities of business, government and society. Table 1 shows the main normative documents that regulate this issue and include environmental requirements and obligations.

\section{Table. 1. Basic international documents on the regulation of social responsibility of business entities}

\begin{tabular}{|c|c|}
\hline DOCUMENT & CREATOR \\
\hline SA8000:2001 Social Accountability & Social Accountability International (SAI) \\
\hline AS 8003-2003 Corporate Social Responsibility & Standards Australia International \\
\hline $\begin{array}{l}\text { - SD 21000:2003 Sustainable development - Corporate social } \\
\text { responsibility } \\
\text { - Draft Standard on Fair Trading }\end{array}$ & Association Fran aisle de Normalisation (AFNOR) \\
\hline $\begin{array}{l}\text { SIGMA Project on Sustainability - Integrated Guidelines for } \\
\text { Management }\end{array}$ & $\begin{array}{l}\text { British Standards Institution, Forum for the Future; } \\
\text { Accountability }\end{array}$ \\
\hline $\begin{array}{l}\text { Draft Israel standard SI } 10000 \text { Social responsibility and } \\
\text { community involvement }\end{array}$ & Standards Institution of Israel \\
\hline $\begin{array}{l}\text { 1. Draft Standard on Ethical Financial Instruments PNE } 165001 \\
\text { 2. Draft Standard on Management System on Ethics PNE } 165010\end{array}$ & Spanish Standards Organisation (AENOR) \\
\hline Global Reporting Initiative Sustainability Reporting Guidelines & Global Reporting Initiative (GRI) \\
\hline Account Ability 1000 Assurance Standard & Institute of Social and Ethical Accountability \\
\hline Benchmarks for Measuring Business Performance & Interfaith Center for Corporate Responsibility \\
\hline Ethics Compliance Management System Standard 2000 & $\begin{array}{l}\text { Reitaku University Business Ethics and Compliance } \\
\text { Research Center }\end{array}$ \\
\hline
\end{tabular}

Source: compiled by the author based on the data of Copenhagen Centre for Corporate Responsibility (2020). 
As the most effective example, it is necessary to provide the activities of the Copenhagen Centre as an independent analytical centre created by the Danish government in 1998 in response to the growing international interest in new initiatives in the field of social partnership and corporate social responsibility (Copenhagen Centre..., 2020). The Centre has developed the concept of voluntary mutually beneficial partnership between representatives of business, the national government and public organisations in order to increase the competitiveness of individual companies and national economies on the basis of sustainable development, business transparency and social responsibility. The main objective of the Centre is to accumulate knowledge and bring together business leaders and political decision-makers to discuss the changing role of business in society.

The 1972 UN Conference in Stockholm began the rapid development of international and state environmental organisations: environmental protection bodies were created in many countries of the world and a United Nations Environment Programme (UNEP) coordinating organisation was formed. Over the following 20 years, a number of states have spent more than a trillion of dollars on environmental monitoring programs. In 1992, at the conference in Rio de Janeiro, in which 179 countries took part, 27 recommendatory principles were proclaimed for a civilisation to achieve sustainable development (United Nations Conference..., 1992). The ideas of environmental responsibility and obligations of states were enshrined in the adopted declaration (Analytical document, 2018). Over the following 20 years, many international documents, programs and initiatives appeared, suggesting both mandatory and voluntary actions by the leaders of countries, large corporations and public groups. The main initiatives are shown in Figure 1. International environmental law consists of a set of norms and principles governing international relations in the field of environmental protection and the rational use of natural resources (Lutkovska, 2020b). At the national level, in almost every country, special regulatory legal acts on environmental protection have been adopted, strategies for sustainable development have been developed and provided various types of liability for environmental violations.

\begin{tabular}{|c|c|}
\hline \multicolumn{2}{|r|}{ The main international documents on the regulation of environmental responsibility } \\
\hline 1992 & The Convention on Biological Diversity \\
\hline 2000 & The Cartagena Protocol on Biosafety \\
\hline 1994 & Protocol to the 1979 Convention on Long-range Transboundary Air Pollution \\
\hline 1997 & UN Framework Convention on Climate Change and the Kyoto Protocol \\
\hline 1998 & $\begin{array}{l}\text { The UNECE Convention on Access to Information, Public Participation in Decision-Making } \\
\text { and Access to Justice in Environmental Matters }\end{array}$ \\
\hline 2001 & Stockholm Convention on Persistent Organic Pollutants \\
\hline 2003 & $\begin{array}{l}\text { Protocol on Strategic Environmental Assessment to the Convention on Environmental Impact } \\
\text { Assessment in a Transboundary Context }\end{array}$ \\
\hline 2006 & The International Tropical Timber Agreement \\
\hline 2004 & $\begin{array}{l}\text { Directive } 35 \text { of the European Parliament and of the Council on environmental liability with } \\
\text { regard to the prevention and remedying of environmental damage }\end{array}$ \\
\hline
\end{tabular}

Fig. 1. The main international documents on the regulation of environmental responsibility Source: compiled by the author based on the data of Eldis website (2020).

The principles of sustainable development are a fundamental prerequisite for healthy entrepreneurship. Well-known global companies (e.g., IBM, General Electric, Ford Motors Corporation, British Petroleum, etc.), along with the strategy for generating economic profit are also 
implementing? a program for generating additional social profit. They have voluntarily abandoned uncivilised ways of doing business that have led to environmental pollution. Acting on the terms of a public-private partnership, business entities, including environmental criteria in its business procedures, are now developing strategies aimed at continuous improvement of environmental performance. The companies are contributing to the solution of the main social and environmental problems facing the planet and the state through the development and implementation of measures aimed at reducing the environmental impact, supporting green business, managing environmental climate risk and preserving biodiversity.

Public-private partnerships in the field of environmental protection in Ukraine are conducted in different directions: openness of environmental information, publication of reports on environmental indicators; public discussions of business development plans and projects, hearings of environmental impact assessments for new enterprises; active discussion of relevant environmental topics in the city, region, country, development of public positions, dialogue with stakeholders. According to the directions of implementing public-private partnerships in Ukraine, businesses seeks to constantly minimise their operational environmental impacts by monitoring environmental performance, setting improvement goals and implementing and evaluating environmental management programs that save energy and water, manage waste, recycle materials, and reduce business travel and promote green procurement. In addition, it helps protect the environment through a wide range of electronic services.

In the Ukrainian legal field, the following Laws of Ukraine should be noted: "On Basic Principles (Strategy) of the State Environmental Policy of Ukraine for the Period to 2030" (2019), "On Environmental Protection" (1991), "On Protection of Atmospheric Air" (1992), "On Natural Reserve Fund of Ukraine" (1992). The authors suggests that codified acts can be divided into two groups: the first one provides for protection standards (Water, Land and Forest Codes and the Subsoil Codes), while the second one provides responsibility for violation (criminal, civil, administrative, labour). In the framework of public-private partnerships in Ukraine, the state undertakes to support green entrepreneurship and finance enterprises and individuals who want to make environmentally friendly investments by providing specialised "green" products offered on relatively favourable terms. In particular, it supports green fields of renewable energy, energy conservation, organic farming, conservation of biodiversity, green chemistry, environmentally friendly transport, water and waste management, restoration of the environment, ecotourism and agritourism. This ensures the responsible use of natural resources and the preservation and creation of jobs. The government of Ukraine provides or supports services and projects to help enterprises and individuals solve environmental problems and adapt to climate change. Particular attention is paid to addressing climate change by reducing carbon dioxide (CO2) emissions and using the opportunities that may develop from climate change. In addition, one of the main principles of the state environmental policy of Ukraine is the stimulation of domestic economic entities that reduce greenhouse gas emissions, reduce energy and resource consumption. It supports business entities whose modernization of production is aimed at reducing the negative impact on the environment, including improving the system of environmental tax on environmental pollution and payments for the use of natural resources (Law of Ukraine No 2697-VIII “On Basic Principles...”, 2019).

Four of the most important environmental objectives for business entities can be identified:

1. Climate conservation. Climate change can lead to irreversible consequences: for example, the melting of glaciers can lead to an increase in the level of the world ocean and flooding of large territories as well as to a shortage of fresh water in territories whose population takes water for its needs from rivers with glacial nutrition. One of the environmental measures in this direction is the reduction of greenhouse gas emissions.

2. Saving natural resources. The results of environmental studies and calculations show that some non-renewable natural resources (e.g., crude oil) will run out in the foreseeable future as well as some renewable resources (e.g., fresh water or forests, since their use is often much faster than their recovery). Environmental measures in this direction could be water conservation, the transition 
to the use of renewable energy sources, the introduction of reverse water use systems, the use of secondary raw materials in technological chains, improving the efficiency of the use of raw materials and resources, using recycling systems for used products and waste, etc.

3. Pollution of the natural environment: air, water bodies, soil, etc. Nature is able to process only a certain amount of "refuse" without human intervention. However, the volume of pollution today exceeds its capabilities to restore equilibrium, which leads to disruption of natural processes. The main measures to overcome this problem are minimisation of emissions, maximum purification of emissions, recycling or disposal of waste, prevention of accidents.

4. Conservation of flora, fauna and ecosystems. In nature, everything is interconnected: the disappearance of one species of animal or plant, or the violation of the landscape can lead to the extinction of other species and cause irreversible consequences for the ecosystem as a whole. Measures to overcome this problem consist in the awareness and assessment of their impact on the biodiversity of the occupied territories, the maximum conservation of landscapes and the restoration of disturbed.

Companies can contribute effectively to the implementation of environmental responsibility by performing the following actions:

- compliance with environmental legislation: state environmental inspection of new facilities, monitoring and evaluation of activities compared to statutory standards, the introduction of environmentally friendly technologies, etc.

- an effective action management system: a strategy has been developed in the field of environmental protection, implementation of systemic technological and/or organisational decisions to minimise the negative impact of products, production and activities, regular evaluation and analysis of the impact of technological processes and products on the environment and human health;

- inclusion in the management system of elements of environmental aspects of the activity at the level of making any decisions. For example, when purchasing paper for office, paper is consciously selected from recycled waste paper; or when choosing a supplier of equipment, not only its cost and quality are taken into account, but also the opportunity to return it at the end of its service life for processing;

- environmental training or education of employees, informing customers, shareholders and the general public about the goals and results of corporate environmental protection measures, which are aimed at improving the environment and quality of life;

- scientific research in the field of environmental protection, monitoring the appearance on the market of new environmental technologies, products and solutions; financial and other types of support for scientific research and public initiatives of legislation.

From the beginning of the development of the company, one or several of the following actions are implemented on the principles of environmental responsibility, but all of them are gradually implemented as far as possible, and in this way, the company becomes "ideally" environmentally responsible. To solve problems in this area and build an effective environmental strategy in the system of public-private partnerships, it is advisable to use the following tools:

- environmental impact evaluation, including strategic environmental evaluation, when developing strategies and plans for economic development (Shulyak, 2018);

- environmental audit which allows early detection of environmental violations (Zinchuk and Levkivsky, 2019);

- environmental insurance: an insured event provides for compensation for environmental damage (Zakharina et al., 2020);

- certification of compliance with environmental standards (international standards of the ISO 14000 series - environmental management, international standard ISO 19011 - audit of quality management systems and/or environmental management systems; national standards for resource conservation and environmental protection) (Kuzhda et al., 2019);

- environmental marketing: promoting eco-innovation (Plakhotnikova and Bulakh, 2019); 
- technological regulation: the introduction of affordable energy-saving and harmless technologies;

- social reporting regarding the environmental component.

The integrated use of these instruments will significantly improve the environmental status of companies, cities, territories, regions and the country as a whole. If it is not possible to completely level out the problem in the global dimension, then it is necessary to minimise the negative impact factors. Many of these measures not only constitute the voluntary responsibility of companies, but also are mandatory as fixed by the state in the form of laws and regulations, and provide for various types of responsibility (i.e., social, corporate, administrative, civil, labour, criminal) if they are not fulfilled. Therefore, in the contribution of business to environmental protection, two areas can be identified: 1) internal, i.e., the company's policy to reduce the impact of its activities on the environment; 2) external, i.e., the policy of increasing the environmental awareness of its customers and counterparties, and public actions to preserve the environment for future generations.

In the field of environmental protection, the legal and economic system of Ukraine can enhance the environmental modernization of industrial enterprises by reducing the environmental tax rate or in the form of a fixed annual amount of compensation (tax refund) (Law of Ukraine No 2697VIII "On Basic Principles...", 2019). It will provide stable funding for environmental activities and stimulate the development of environmental entrepreneurship that consists in the production of products, performance of work and provision of environmental services. According to Law of Ukraine No 2697-VIII (2019) these mechanisms will help create a tax, credit and investment climate to attract international donors and private capital to environmental activities. It will also lead to the creation of environmental management systems by business entities, the introduction of cleaner production, resource and energy saving technologies, and expanded forest reproduction. However, public-law partnership is difficult to implement in practice.

Hence, in environmental responsibility, three components should be identified: social, legal and economic. Legally, environmental responsibility is the obligation to eliminate, compensate, reimburse for the adverse consequences of a committed environmental offense in accordance with the sanction of the violated rule of law. The legal component is caused by unlawful activity, which led to a violation of environmental law and is regulated by administrative and legal methods. The social component of environmental responsibility is a consequence that is viewed as reputational losses, loss of trust of interested parties and the public, risk of violation of sustainable development. The economic part of environmental responsibility is based on legitimate activities and is regulated by economic methods (e.g., material interest in compliance with environmental standards, material losses for violations, additional environmental profit for waste processing, etc.). Thus, environmental responsibility as a component of a socially responsible business entity should be understood as public-private and public relations regarding the initiative, voluntary and peremptory obligations of the businesses to comply with the environmental criteria of activity in order to minimise the negative impact and maximise the positive impact on the environment, society and people accompanied by protectionist and motivational measures from the state.

\section{Conclusions}

1. Corporate environmental policy is an integral part of a business strategy and must be accompanied by environmental literacy and strict adherence to environmental standards.

2. The main objectives of environmental management for business structures in the framework of public-private partnerships in Ukraine are based on the results of the study conducted and suggest the following: 1) full possession of information on environmental protection legislation, ensuring its compliance; 2) monitoring the implementation of environmental policies by regularly conducting checks for compliance with established requirements; 3) ensuring that staff comply with environmental policy provisions; promoting the activities of suppliers, contractors and distributors in the framework of environmental policy; 4) choice of technologies that exclude environmental pollution, minimising waste, reuse and processing of resources and reduce energy consumption; 5) 
active participation in solving environmental problems at the local level, implementing public projects, raising public awareness in the field of environmental protection.

3. These goals are important to the state, business and society; and they can be achieved by applying control, monitoring and measurement methods for all processes involved in the design and production of products or services, procurement and cooperation, support, etc. As part of the application of environmental policy and achievement of existing or revised environmental goals and objectives, the government of Ukraine should facilitate the receipt of all necessary resources and implement environmental management programs involving all interested parties..

\section{References}

1. Aleksandrova, T.V. 2019. "Development of corporate environmental responsibility of the oil and gas business in the transition to a "green" economy." Management Consulting, 9: 55-70.

2. Alekseeva, A. 2008. "Us and them: the truth about social responsibility." Companion, 9(577): 26-56.

3. Analytical document "Environmental responsibility: EU experience and opportunities for Ukraine". 2018. https://www.civic-synergy.org.ua/wp-content/uploads/2018/04/webenvironmental-liabilityua2018.pdf [2020-10$20]$.

4. Bowen, H.R. 1953. Social responsibilities of the businessman. New York: Harper \& Row.

5. Chernykh, E.V. 2009. "Features of corporate social responsibility." Economic Bulletin of Donbass, 3(17): 11-16.

6. Copenhagen Centre for Corporate Responsibility. 2020. https://www.eldis.org/organisation/A8214 [2020-10-20].

7. Eldis. 2020. https://www.eldis.org/ [2020-10-20].

8. Kopytova, E.D. 2017. "On the issue of social and environmental responsibility of business." Territorial Development Issues, 4(39): 1-10.

9. Krupina, N.N. 2006. Basics of business nature management. Pyatigorsk: Pyatigorsk State Linguistic University.

10. Kuzhda, T., Lutsykiv, I., and Shveda, N. 2019. "Development of environmentally responsible business in Ukraine and the world." Socio-Economic Problems and the State, 21(2): 246-258.

11. Ladunka, I.S., and Simonenko, D.A. 2017. "Ecological social responsibility of enterprises in Ukraine." Economics and Society, 13: 917-923.

12. Law of Ukraine No 1264-XII “On Environmental Protection”, on June $25,1991$. https://zakon.rada.gov.ua/laws/show/1264-12\#Text [2020-10-20].

13. Law of Ukraine No 2456-XII "On Nature Reserve Fund of Ukraine", on June $16,1992$. https://zakon.rada.gov.ua/laws/show/2456-12\#Text [2020-10-20].

14. Law of Ukraine No 2697-VIII "On Basic Principles (Strategy) of the State Environmental Policy of Ukraine until 2030”, on February 28, 2019. https://zakon.rada.gov.ua/laws/show/2697-19\#Text [2020-10-20].

15. Law of Ukraine No 2707-XII "On Protection of Atmospheric Air", on October 16, 1992. https://zakon.rada.gov.ua/laws/show/2707-12\#Text [2020-10-20].

16. Malinovska, O.Ya. 2008. "Social responsibility of business in Ukraine: stages of formation." Collected Works of the National Forestry University of Ukraine, 18(6): 200-204.

17. Meadows, D.H., Meadows, D.L., Randers, J., and Behrens III, W.W. 1972. The Limits to Growth: A Report for the Club of Rome's Project on the Predicament of Mankind. New York: Universe Books.

18. Osobajo, O.A., Otitoju, A., Otitoju M.A., and Oke, A. 2020. "The impact of energy consumption and economic growth on carbon dioxide emissions." Sustainability, 12: 7965.

19. Plakhotnikova, L.O., and Bulakh, T.M. 2019. "Ecological marketing in the system of formation of social responsibility of business." Scientific Bulletin of the National Academy of Statistics, Accounting and Auditing: Collection of Scientific Papers, 4: 101-108.

20. Postal, L.G., and Komelkova, M.V. 2017. "Social responsibility of business: world tendencies and domestic features." Financial Analytics: Problems and Solutions, 10(8): 895-911.

21. Saprykina, M. 2008. "On the way to social responsibility." Mirror of the Week, 19(698): 21-28.

22. Shevchenko, I.L. 2015. "Environmental responsibility in the practice of corporate governance of the largest Russian companies." Bulletin of the Kuzbass State Technical University, 5: 190-197.

23. Shulyak, B.V. 2018. Development of ecologically oriented business in rural areas. Zhytomyr: Zhytomyr National Agroecological University.

24. United Nations Conference on Environment and Development, Rio de Janeiro, Brazil, 3-14 June 1992.1992. https://www.un.org/en/conferences/environment/rio1992 [2020-10-20].

25. United Nations Conference on the Environment, 5-16 June 1972, Stockholm. 1972. https://www.un.org/en/conferences/environment/stockholm1972 [2020-10-20].

26. Uskova, T.V., and Kopytova, E.D. 2016. "Corporate social responsibility: the state and tools of development." Problems of Territory's Development, 6(86): 7-19.

27. Vorobey, V. 2005. “Corporate social responsibility or benefit?” Kyiv-Mohyla Business Studio, 10: 18-29. 
28. Yarova, V.V. 2013. "Theoretical and methodological approaches to the study of corporate social responsibility." Bulletin of Kharkiv National Agrarian University. Series: Economic Sciences, 5: 185-196.

29. Zinchuk, T.O., and Levkivsky, E.V. 2019. "Corporate social responsibility of vertically integrated structures of agrarian business as a condition of sustainable development." Economics of APK, 1: 39-44. 30 .

\section{Anatoliy V. Kostruba}

\section{Imonių atsakomybẻ aplinkos apsaugos srityje: viešojo ir privataus sektorių partnerystė}

\section{Anotacija}

Asmeninè ir verslo atsakomybė yra darnaus visuomenès ir pasaulio vystymosi pagrindas. Verslo subjektų atsakomybė už aplinkos apsaugą yra būtina sąlyga žmonių išlikimui, todėl tai yra svarbus įmonès atsakomybės aspektas. Straipsnio tikslas - nustatyti verslo subjektų korporacinès ir socialinès atsakomybių aplinkos apsaugos srityje turinį, sąveikas su valstybiniu sektoriumi atsivelgiant $\mathfrak{i}$ viešojo ir privataus sektorių partnerystę. Naudojant palyginimą buvo ịvertinta Ukrainos aplinkos apsaugos teisinè bazė bei teisinio reguliavimo sistema. Atlikus struktūrinių ir funkcinių ryšių analizę, buvo galima ịvertinti valstybès ir verslo struktūrų bei kitų institucijų, kurių veikla susijusi su aplinkos apsauga, sąveikos ypatumus. Tyrimas atskleidè, kad būtiną įrodyti poreiki apsvarstyti ir įtraukti verslo aplinkosaugos ir socialinès atsakomybès elementus i viešojo ir privataus sektorių partnerystès mechanizmus. Daroma išvada, kad viešojo ir privataus sektoriaus partnerystè yra būtinas socialinès atsakomybès sudedamosios dalys. Pateikiamas autoriaus atsakomybès už aplinką apibrèžimas ir siūloma sudaryti tris veiksnius: teisinį, ekonominị ir socialinį. Ateityje ši mokslinių tyrimų srities svarba augs, todèl būtina plèsti žinias ir suvokimą apie teisinę paramą atsakomybių igalinimui, ypač pasinaudojant užsienio ir tarptautinių organizacijų patirtimi diegiant aplinkos apsaugos politikos priemones standartus tipams, atsižvelgiant $i ̨$ atitinkamų Ukrainos teisinès sistemos standartų igyvendinimą ir jų igyvendinimą praktikoje.

Anatoliy V. Kostruba - Full Doctor in Law, Professor at the Department of Civil Law, Vasyl Stefanyk Precarpathian National University, Ivano-Frankivsk, Ukraine

E-mail: kostruba5467-2@kpi.com.de

Anatoliy V. Kostruba - teisès mokslų daktaras, profesorius Vasil Stefanyk Precarpathian National Universitetas, Civilinès teisès fakultetas, Ukraina

El. paštas: kostruba5467-2@kpi.com.de 